\title{
Countermeasures and Suggestions on the Tourism Image Design of the CIS Introduction in Shenyang
}

\author{
Yan Dong ${ }^{1, ~ a ~}$ \\ ${ }^{1}$ Dalian University Of Science And Technology
}

No.999-26, bingang road, Ivshun economic development zone, dalian, liaoning province, China

a274261074@qq.com

Keywords: Shenyang; tourism image design; countermeasures and suggestions

Abstract: The construction of city brand and tourism brand image is an important proposition affecting the development of a city. The corresponding research and practice have been widely carried out in the domestic tourist cities. As the economic, political and cultural center among the three northeastern provinces, the lack of urban brand image in Shenyang is an unfavourable factor during the process of constructing a national central city. Also problems in Shenyang's city brand construction are analyzed in detail in this paper. And following countermeasures and suggestions has been put forward: the relevant government departments should strengthen the brand awareness, the role of regional culture in shaping the Shenyang's tourism image should be fully played, the brand design should be selected through a variety of channels, and the popularity of Shenyang's tourism brands has been raised with the help of large events and festivals.

\section{The current situation of CIS brand strategy implementing in domestic cities}

The section headings are in boldface capital and lowercase letters. Second level headings are typed as part of the succeeding paragraph (like the subsection heading of this paragraph).

The Importance of the CIS Introduction Strategy about Brand Image of the City The Unique City Image Can Offer Helps in the Charm and Attraction of the City

A city without special features or brand image is unattractive to everyone. And the excellent city image can effectively improve the charm and attraction of the city, which plays a unique role in attraction of talent, investment and tourism.

The Unique City Brand Position Can Offer Guidance in the Development and Promotion of the City

If a brand is full of vitality, it must be more attractive, inspiring, and capable of holding people's minds and hearts. City brand positioning does not only reflect the real products provided by the city, but can also guide the development and promotion of the city.

\section{The Unique City Brand Image Can Offer Helps in the Regional Culture Protection}

Regional historical culture and geographical resources are not only the foundation and source of the city image, but also the original elements of the difference in it. The emphasis on city geo recognition can make the city image equipped with more personality elements. Further more, it can also inherit the culture of regional characteristics and make it more radiant indeed.

\section{The General Situation about Brand Image Design Introducing in Domestic Cities}

According to the survey data of 2016, 34 provincial administrative regions have their own tourism image design in China. Among the "Best Tourist City", "Excellent Tourist City" and other major municipal administrative areas, $41 \%$ of them have a tourist image. These provinces and regions are mainly distributed in the eastern, southern and central regions of China, especially in southeastern coastal areas, with Jiangsu, Guangdong and Zhejiang provinces as dense areas ${ }^{[1]}$. This phenomenon shows that the application of urban tourism image in China is closely related to regional tourism resources and the degree of economic development indeed.

As far as design effect is concerned, many city brand designs still need to be improved and improved. There are many deficiencies in tourism logo: information transmission is not accurate; graphics are too simple; lack of formal beauty and cultural connotations; lack of visual language and 
design concept innovation. Such a design not only offer not help in the tourism image promotion of a city, the dissemination of regional culture, or the creation of business value, but also have negative affects on the overall image of a city. ${ }^{\text {(Fig. 1) }}$

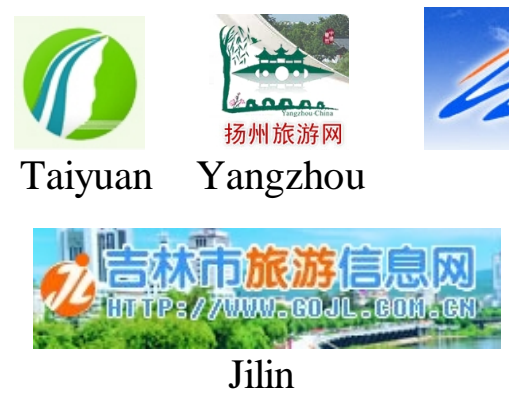

Jilin



Nantong

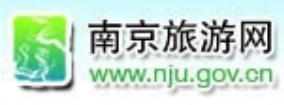

Nanjing



Rizhao

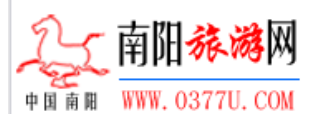

Nanyang

Fig. 1 Some Urban Tourism Logo Design

\section{The Problems Existing in the Promotion of Tourism Brand and the Image of Shenyang}

According to the Chinese city innovation Report, Shenyang ranked seventeenth in 2015, seventeenth in 2016, and sixteenth in 2017 in the evaluation of "brand innovation ability" within sub provincial and above cities. Among the cities of the same level in the country, it is in the low-ranking. ${ }^{[2]}$

Brand innovation ability reflects the reputation of the city as well as the brand influence of the city's products. To a certain extent, this shows that there are some shortages for Shenyang in the shaping of city popularity and the promotion of brand influence.

\section{Lacking in Urban Brand Logo of Shenyang}

Shenyang, a famous cultural city with the history of 2300 years, is one of the first excellent tourist cities in China. But its city logo is just a blank space. In the process of developing tourism economy, it simply propagates and publicizes its tourism resources, with no brand logo which is distinct, symbolic and can reflect Shenyang's history and culture created.

\section{The Publicity of the City Brand Image in Shenyang is Weak}

In the media such as the comprehensive channel, the news channel and the Chinese international channel of CCTV, a wide range of tourist destinations will be broadcast daily, which has a good publicity effect on the dissemination of the city brand and the promotion of tourism consumption.But Shenyang nearly has nothing to do in this respect. Further more, in other media and publicity channels, we still can not tell the "watching focus" about Shenyang city brand publicity.

\section{Lacking in Overall Brand Development Strategy of Shenyang}

Shenyang has many influential tourism products: Imperial Palace in Shenyang, Fuling Mausoleum, Zhaoling Mausoleum, General Zhang's mansion and the New Music Sites are well-known to us, both far and near. But the outstanding problem is that the city brand image is not prominent, and lack of integration. Also, the image of the scenic spots can not represent the overall tourism image of Shenyang. So the top priority task is to implement the overall brand development strategy. Shenyang's tourism resources and tourism products should be reintegrated to create a unified city tourism brand with a strong market appeal.

\section{Poor Incidental Consumption and Insufficient Vitality in the Tourism Market}

Because the features of Shenyang's geographical landscape image, cultural landscape image, core section image and tourism enterprise image are not obvious, together with inaccurate positioning and grasping, lacking in brand image, the incidental consumption of tourism is not in a goog situation and the tourist commodities are difficult to meet the needs of consumers. These has become barrier factors in the development of Shenyang's tourism. 


\section{Countermeasures and Suggestions on the Tourism Image Design of the CIS Introduction in Shenyang}

The Relevant Government Departments Should Strengthen the Brand Awareness and Attach Great Importance to the Shaping and Publicity of the Tourism Image in Shenyang

Brand is a huge intangible asset of a city, an important factor to improve the competitiveness of urban tourism, a necessary means to enhance urban taste and an important measure to tap the potential of urban sustainable development.At present, many cities have been aware of the great significance of brand development and have made their own brands ${ }^{\text {(Table 1, Table 2) }}$.

Table 1 Part of the Brand Culture List within Domestic Cities

\begin{tabular}{|c|c|c|c|}
\hline City & Brand and Characteristic & City & Brand and Characteristic \\
\hline Shanghai & $\begin{array}{c}\text { Oriental Charm City, } \\
\text { Oriental Pearl }\end{array}$ & Dalian & $\begin{array}{c}\text { Romance Capital, Garden } \\
\text { City }\end{array}$ \\
\hline HongKong & Asian International Capital & Hangzhou & $\begin{array}{c}\text { The paradise on Earth, the } \\
\text { Capital of Leisure }\end{array}$ \\
\hline Guangzhou & $\begin{array}{c}\text { Flower city, Eastern Port of } \\
\text { the Silk Road on the Sea }\end{array}$ & Shenzhen & $\begin{array}{c}\text { The Wonderful Shenzhen } \\
\text { and the Capital of Joy }\end{array}$ \\
\hline Nanjing & $\begin{array}{c}\text { Rock City, the Ancient } \\
\text { Capital of the Six Dynasties }\end{array}$ & Kunming & $\begin{array}{c}\text { Spring City,Spring-liking for } \\
\text { Four Seasons }\end{array}$ \\
\hline Changsha & $\begin{array}{c}\text { Star City, Entertainment } \\
\text { Culture }\end{array}$ & Chongqing & $\begin{array}{c}\text { Everyone of Chongqing, } \\
\text { Mountain City }\end{array}$ \\
\hline Nanchang & Modern Army Capital & Jingdezhen & Chinese Porcelain Capital \\
\hline
\end{tabular}

Table 2 Part of the Brand Culture List of Foreign Cities

\begin{tabular}{|c|c|c|c|}
\hline City & Brand and Characteristic & City & Brand and Characteristic \\
\hline Munich & Capital of Beer & $\begin{array}{c}\text { Los } \\
\text { Angeles }\end{array}$ & International Film Capital \\
\hline Dubai & $\begin{array}{c}\text { City of Sports in the Middle } \\
\text { East }\end{array}$ & $\begin{array}{c}\text { Hanoveria } \\
\mathrm{n}\end{array}$ & Capital of the Fair \\
\hline Osaka & Sports Amusement Park & Geneva & $\begin{array}{c}\text { Capital of International } \\
\text { Conferences }\end{array}$ \\
\hline Vienna & Capital of Music & Bene & Capital of the Clock \\
\hline Venice & City of Water & Hawaii & Capital of Tourism \\
\hline
\end{tabular}

In shaping the city brand, the relevant departments of the Shenyang municipal government should also improve their own understanding to strengthen the macro guidance of the city brand construction, and to clarify the guiding ideology, policy and basic ideas of Shenyang's brand development. They should also design and plan the brand image of Shenyang well around the goal of creating the "National Central City" indeed.

Giving Full Play to the Role of Regional Culture in Shaping the Tourism Image of Shenyang

In the process of building the city brand image, the development of regional culture is the basis of displaying the character of the city. It not only creates conditions for the design of city brand logo, but also can inject vitality into the city spirit and slogan concise.

Regional cultural factors include the legend of the city, cultural events, and various cultural heritage resources such as folk activities and folk art. Legend stories, such as the legend of Guangzhou's five sheep, the legend of the mermaid in Copenhagen, has all become the cultural gene of the city brand; 
And Eight Eccentrics of Yangzhou, The Tongcheng School of Anhui, Jiangxi path-breaking debate have become the city's cultural events.

The unique historical and cultural resources of our city, such as Xinle culture, the minority culture in the northeast frontier, The Manchu culture, the modern political and historical culture, the industrial manufacturing culture, are taken as the support. Advantage of intangible cultural heritage, such as Northeast Drum, Fengtian Laozi,Pingju, Peking Opera, Xibe Xili Mama,Shadow Puppet, Manchu paper-cut, are regarded as images and modeling elements. We should dig deeper into the cultural point, and carry forward the regional culture of Shenyang with brand mark and CIS design introduction, so as to equip Shenyang's city image with profound cultural details.

Carrying Out "Shenyang Tourism Sign Collection Activities", Multi Channels for Selection in Design Scheme

The city symbol is the final extraction of the cultural construction of the city's characteristic, and it is also the whole reaction of the city culture. In 2001, Hongkong launched the "Hongkong Logo - Flying Dragon". It takes the new positioning of the city brand, "Asia's world city", to represent Hongkong's role transformation and strategic repositioning adjustment in the process of global economic integration. ${ }^{\text {(Fig. 2) }}$

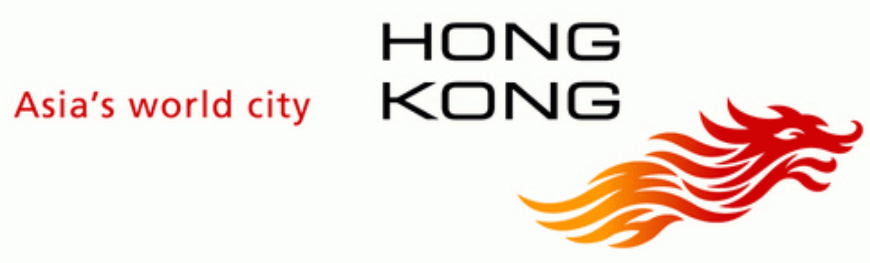

Fig. 2 Hongkong Logo - Flying Dragon

As for setting up the tourism image of Shenyang, the design of "Shenyang tourist sign" is a core element. Therefore, a lot of work should be spent on the collection and selection of excellent design. And "Shenyang Tourism Logo Design Competition" can be carried out with information disseminated to society through many channels, such as networks, television, and newspapers. And the design of "Shenyang Tourist Logo" is selected through the events and the design of directional entrustment. In the end, logo selected should highlight the mainstream elements, the well-known elements, the local scenery features and historical and cultural characteristics of the principle. This action can not only collect the logo works, but also can improve the popularity of Shenyang and expand the effect of publicity.

With the Promotion of Shenyang Tourism Logo as the Core, the City Identification System (CIS) is Established to Strengthen the Publicity.

Taking the Shenyang tourism logo as the core, CIS - the City Identity System has been introduced. Excellent CIS design enables tourists to identify the cities it represents while accepting various image information. And good impressions and good associations can be produced in their minds. The system consists of three aspects: mind identification system (MIS), behavior Identification system (BIS) and vision identification system (VIS). 
Table 3 Design Content of City Tourism Identification Systems

\begin{tabular}{|c|c|c|}
\hline $\begin{array}{c}\text { Mind } \\
\text { Identification System (MIS) }\end{array}$ & $\begin{array}{c}\text { Behavior Identification System ( } \\
\text { BIS) }\end{array}$ & $\begin{array}{c}\text { Vision Identification System } \\
\text { (VIS) }\end{array}$ \\
\hline $\begin{array}{l}\text { The main tourist } \\
\text { characteristics and style of } \\
\text { the city; } \\
\text { The purpose and target } \\
\text { image of urban tourism } \\
\text { development; } \\
\text { The principles and methods } \\
\text { of tourism management; } \\
\text { The slogan of tourism } \\
\text { propaganda. }\end{array}$ & $\begin{array}{l}\text { Recognition External } \\
\text { The market survey and product } \\
\text { development of tourist source; } \\
\text { Public relations activities and } \\
\text { marketing promotion of urban } \\
\text { tourism; } \\
\text { The public welfare activities and } \\
\text { cultural activities of the city. } \\
\text { Recognition Internal } \\
\text { The city's CTI publicity for part } \\
\text { of public (citizens) in the city; } \\
\text { The cooperation of all kinds of } \\
\text { tourism enterprises; } \\
\text { The management system and } \\
\text { management method of urban } \\
\text { tourism; } \\
\text { The training of tourist } \\
\text { employees; } \\
\text { The formulation and } \\
\text { implementation of urban tourism } \\
\text { development plan. }\end{array}$ & $\begin{array}{l}\text { Urban tourist signs; } \\
\text { The standard character of } \\
\text { urban tourism; } \\
\text { The standard color of urban } \\
\text { tourism; } \\
\text { Urban tourism representative } \\
\text { image design; } \\
\text { Determination of city flower, } \\
\text { city badge, and city tree, and } \\
\text { Logo design; } \\
\text { The production of the } \\
\text { characteristic songs of the city } \\
\text { tourism; } \\
\text { Design of tourism advertising, } \\
\text { tourism Handbook, map, } \\
\text { postcard, video and so on }\end{array}$ \\
\hline
\end{tabular}

Under the guidance of the CIS strategy, taking the domestic large-scale exhibition, tourism promotion activities as the carrier, and news reports and television, network, radio, newspaper and outdoor advertising as main forms of publicity, a full range of Shenyang tourism brand promotion in multi-level can be carried out absolutely.

Improve the Popularity of Shenyang Tourism Brand with the Help of Large-scale Events and Festivals

Combining its own characteristics, many foreign cities have made use of the law of cultural development to publicize the city brand. For example, "the capital of music" Vienna takes classical music as the breakthrough point of the city brand. Paris has become the focus of the world through hosting large sports events (World Cup, World Athletics Championships, Rugby World Cup) and cultural activities (Sino French cultural year); Seoul, South Korea, also made the city's image unprecedented and promoted by the international community through the 1988 Olympic Games and the 2002 World Cup football match indeed ${ }^{[3]}$.

According to the data of Shandong Provincial Tourism Bureau, 5 million 698 thousand tourists were received in the three days of new year's day in 2016, with the total tourism revenue in 2 billion 890 million yuan, which is increased by $25 \%$ over the same period in last year."Hospitable Shandong New Year Carnival" Tourism Festival's stimulation in tourism consumption was very obvious.

Shenyang should also show the splendid and best side of the city to tourists through large festivals and events. Therefore, in the brand building, Shenyang should pay attention to the cultivation of the festival activities. They should carry out various tourism festival activities to disseminate the city brand image of Shenyang, such as Shenyang Qing Culture Festival, World Horticultural Exposition, Shenyang International Ice and Snow Festival, Gourmet Festival,etc. 


\section{References}

[1] Hongdong Cao, "Thinking on the creation of Wuxi city brand during '12th Five-Year Plan'”, Jiangnan Forum, 11th phase of 2010, p.8

[2] China urban innovation report group, China's urban innovation report in year of 2015, 2016 and 2017, http://www.chinacity.org.cn

[3] Weiyan, Promoting Social and Economic Development by Urban Brand Image Construction, Journal of Northeast Dianli University, the Third phase of thirty-first volume, June 2011, p.90 